\title{
ÁNGeles MASTRETTA: MUJeRES, REVOLUCIÓN Y MELOdRAMA
}

\author{
Alejandro José López Cáceres \\ Universidad del Valle
}

\begin{abstract}
Resumen: En este artículo se analiza la obra ficcional de la escritora Ángeles Mastretta. Y nos detenemos en tres de sus aspectos más destacados y polémicos: su relación con el feminismo, su manera de revisitar la historia mexicana del siglo XX y su inclinación hacia el melodrama. Iniciamos recogiendo las principales descalificaciones que la crítica literaria ha realizado contra esta autora y contra su narrativa. Sin embargo, leemos tales reprobaciones en el contexto general de los debates surgidos a propósito del "post-boom" latinoamericano. Esto significa considerarlas a la luz de las transformaciones que se presentaron -durante las postrimerías de nuestro siglo $\mathrm{XX}$ - respecto de los paradigmas literarios aportados y legitimados desde el llamado Boom. En relación con el primer aspecto, hacemos notar cómo - al carecer de una concepción orgánica o programática- el punto de vista de esta narradora es más bien femenino que feminista. A propósito de su mirada sobre el México revolucionario y post-revolucionario, destacamos su visión crítica e iconoclasta, así como su valioso énfasis en el ámbito de la vida privada de aquellos que ejercen el poder. Finalmente, nos detenemos a revisar el mayor reparo a partir del cual los críticos de Mastretta se niegan a reconocerle algún valor literario a su trabajo; esto es: su filiación con un insumo representacional tan denostado como el melodrama. En nuestro examen, no obstante, operamos de un modo menos prejuiciado. De allí que escudriñemos el proceder heterodoxo de Mastretta frente a este género; es decir, la manera en que lo parodia, lo ensancha, lo enriquece.
\end{abstract}

Palabras clave: Ángeles Mastretta; Post-boom latinoamericano; melodrama; narrativa mexicana; narrativa latinoamericana del siglo $\mathrm{XX}$.

Recibido: 18 de septiembre de 2016

Aprobado: 30 de noviembre de 2016 .

*Especialista en prácticas audiovisuales y magíster en literaturas colombiana y latinoamericana de la Universidad del Valle. P.h.D. en Literatura y Medios de Comunicación de la Universidad Complutense de Madrid. Premio Jorge Isaacs 2016, en la categoría de Ensayo, con la obra El arte de la novela en el post boom latinoamericano. Profesor de la Universidad del Valle. 


\title{
Ángeles MASTRETTA: WOMEN, REVOLUTION AND MELODRAMA
}

\begin{abstract}
This article analyzes the fictional work of writer Ángeles Mastretta, considering three of its most outstanding and polemic issues: its relation with feminism, its way of revisiting Mexican twentieth century history, and its inclination toward melodrama. We start out by reviewing the main disqualifying articles of literary critics against the author and her work. However, our reading of these censuring words is done in the overall context of debate on the LatinAmerican "post-boom". This implies approaching them in the face of transformations during the latter part of the twentieth century regarding literary paradigms provided and legitimated by the boom. As to the first issue, we observe that her point of view falls short of an organic or programmatic conception and is more a feminine than a feminist approach. As to the revolutionary and post-revolutionary Mexico, we highlight her critical and iconoclastic focus, as well as her valuable emphasis on the private lives of those in power. Finally, we review the main objection of Mastretta's critics, based on which her work is denied literary value; specifically her filiation to a representational input as vilified as melodrama. Our assessment, however, is much less prejudiced. Thus we scrutinize Mastretta's unorthodox treatment of this literary genre; in other words, the way in which she makes parody, and broadens and enriches it.
\end{abstract}

Key words: Ángeles Mastretta; Latin American post-boom, melodrama; Mexican narrative; twentieth century Latin American narrative.

\section{1. Ópera prima y celebridad súbita}

Cuando Ángeles Mastretta publicó su primera novela, Arráncame la vida (1985), ya su carrera como periodista había avanzado con notoriedad. Tras lograr sus primeras colaboraciones en revistas y periódicos mexicanos de gran circulación, como Excélsior, Unomásuno, El Proceso y La jornada, el diario Ovaciones contribuiría en la consolidación de su escritura al encomendarle una columna de opinión, "Del absurdo cotidiano". También es cierto que ya Mastretta había llevado a cabo importantes labores en el entorno artístico mexicano, tales como la dirección —en la ENEP-Acatlán- de la oficina de Difusión Cultural (1975-1977), o la dirección del Museo del Chopo (1978-1982). Entre 
1982 y 1985 tuvo una activa participación en la publicación feminista FEM. Su trabajo periodístico y literario continuaría su ascenso en los años venideros, como lo indica su participación en el programa de entrevistas televisivas "La almohada" (1988), o su vinculación como colaboradora permanente de la Revista Nexos, desde 1991, a través del espacio titulado "Puerto Libre" — de gran importancia en su obra posterior-. Con todo, el reconocimiento más significativo le ha llegado a Mastretta gracias a su obra literaria, en la atracción de innumerables lectores en más de 16 idiomas o en premios tan representativos como el Mazatlán de 1986 —el cual le fuera otorgado por su ópera prima- y el Rómulo Gallegos de 1997 —recibido por su segunda novela, Mal de amores - No olvidemos que su temprana inclinación literaria la había llevado a beneficiarse en 1974 con una beca del Centro Mexicano de Escritores. Sobre sus inicios nos dice Ana Solanes:

Ángeles Mastretta (Puebla, 1949) comenzó dedicándose al periodismo hasta que, animada por uno de sus jefes a que buscara nuevos valores literarios para publicar en una colección que iban a crear, decidió que ella debía encabezar la lista y lanzarse a contar, en forma de novela, alguna de esas historias que hasta el momento guardaba en su cabeza. En realidad, de alguna forma, ya practicaba la ficción desde el periodismo pues, como ella misma cuenta, siempre estuvo peleada con la actualidad, siempre tendía a fabular y, hasta cuando le encargaban un reportaje en su época de estudiante, acababa inventando las historias, aunque, eso sí, su imaginación y talento ya deberían ser notables cuando uno de sus profesores, tras felicitarla por su crónica inventada, le dijo: "Está muy bien, lo que ocurre es que tú no eres periodista, eres escritora". ${ }^{1}$

Habiéndose trasladado a la ciudad de México desde 1971 — tras la muerte de su padre-, Ángeles Mastretta se tituló posteriormente en comunicaciones en la Universidad Nacional Autónoma de México. Su vocación por la literatura la llevaría a iniciarse en la escritura poética, como lo indica aquel primer libro publicado en 1978: La pájara pinta; sin embargo, sería el trabajo narrativo lo que acabaría cautivando

${ }^{1}$ Solanes, Ana. "Ángeles Mastretta: La sabiduría es una forma de la inteligencia del alma". En: Cuadernos Hispanoamericanos, $\mathrm{N}^{\circ}$ 696. Madrid, 2008. Págs. 127, 128. 
finalmente su atención. Ante la pregunta sobre cómo discurrió la escritura de aquella exitosísima ópera prima en el género novelístico y cuánto tiempo le tomó, Mastretta dijo: "Un año. No fue tanto. Cuando empecé a escribir 'Arráncame la vida' tenía un bebé de año y medio, y estaba embarazada de otro. Empecé muy tarde: sólo tuve dos hijos, pero entre los 31 y los 34 . Entonces tuve dos bebés, uno en la barriga y otro afuera, y una novela". ${ }^{2}$

Seguramente jamás esperó Mastretta que su novela alcanzara los desorbitados niveles de popularidad a que llegó. Tampoco se habría esperado que, como ocurre con toda moneda, tanto éxito trajera incluida su contracara. Lo cierto es que la crítica procedente de la academia tuvo, desde un comienzo, fuertes palabras de desaprobación para la autora y para su obra. ${ }^{3}$ Regresaremos luego sobre este fenómeno común a otras novelas escritas por mujeres durante aquellos mismos años y que - miradas las cosas de manera un poco más extensiva- resultó un denominador común a la novelística del post-boom latinoamericano. Detengámonos por ahora a destacar las palabras que sobre este particular ha señalado la investigadora María Ángeles Cantero Rosales:

En efecto, por una parte, estos relatos han inundado el mercado internacional gracias a su rotundo éxito, procedente de la extraordinaria acogida de un público mayoritariamente femenino; por otra parte, han recibido la acusación lanzada por un sector de la crítica especializada de inundar el mercado con "novelas rosas" carentes de valor literario (...) Los títulos que han alcanzado mayores índices de popularidad (...) son: La casa de los espiritus (1982) de Isabel Allende y Arráncame la vida (1985) de Ángeles Mastretta. Ambos llegaron a ser estruendosos best-sellers, acaso en parte debido a su aparente sencillez, falta de pretensiones y de originalidad. ${ }^{4}$

\footnotetext{
${ }^{2}$ Telchman, Ron. "Con la precisión del arrebato". En: Revista Nexos, № 112. México, 1987.

${ }^{3}$ Recordemos en este punto a una de las detractoras más duras de Mastretta, Sara Sefchovich, quien afirmó en su momento: “'Arráncame la vida’ es una propuesta narcisista: la mujer es siempre la más bella, la más inteligente, la más rica, la más poderosa. Se divierte sin culpa, se libera de sus responsabilidades sin remordimiento y nunca sufre de verdad, y por si fuera poco un final feliz le augura el mejor de los futuros. Se trata de un personaje que, vestido de mujer, realiza el sueño de todos los clasemedieros de hoy: la riqueza, el poder y la libre sexualidad".

Sefchovich, Sara. México: país de ideas, país de novelas. Una sociología de la literatura mexicana. Grijalbo. México, 1987. Págs. 228 y ss.

${ }^{4}$ Cantero Rosales, María Ángeles. El "Boom femenino" hispanoamericano de los años ochenta, un proyecto narrativo de "ser mujer". Universidad de Granada. Granada, 2004. Págs. 113,114 .
} 
Al igual que ocurrió con otros novelistas del llamado post-boom en nuestro continente, Mastretta se ha instalado desde el principio en las antípodas del escritor erudito. En dicha perspectiva, su posición está fuertemente influida por aquel fenómeno de época que pugna por desmarcarse del estereotipo heredado del Boom latinoamericano, el cual hacía coincidir la figura del escritor con la del intelectual —en el sentido que entiende dicha condición como la de alguien que opina contestataria y públicamente sobre los más diversos temas y que profesa una especie de permanente cátedra abierta, al mejor estilo de un Vargas Llosa, un Carlos Fuentes, o un Julio Cortázar- En evidente contraste, la suya ha sido una actitud por completo inclinada hacia la cultura popular y, sobre todo, proclive a adoptar los parámetros estéticos que pasan por la cultura de masas. En este sentido, su discurso público ha expresado de modo explícito y provocador su alejamiento de cualquier bibliofilia; muy por el contrario, sus palabras han reivindicado con insistencia la validez de insumos culturales tradicionalmente desacreditados, tales como el melodrama, el bolero o las supersticiones populares. ${ }^{5}$ En la entrevista que ya hemos citado, Mastretta le dice al catedrático norteamericano Ron Telchman:

Yo no tuve una vida formada en la literatura. Crecí en una casa en la que leer era como perder el tiempo. Había que hacer cosas útiles y hacer cosas útiles era aprender a guisar, a bordar y, en el mejor de los casos, a ganarse la vida con una profesión que podía ser hasta médico o aboga-

\footnotetext{
${ }^{5}$ A propósito de las supersticiones, Mastretta reelabora incluso algunas de estas prácticas y las enriquece estilísticamente. Así ocurre, por ejemplo, con los conjuros. A través de éstos la autora realiza cantos de batalla, absolutamente vitalistas, con los cuales caracteriza a sus personajes femeninos. Podemos leer este recurso en diferentes puntos de su obra: en el relato que cierra su libro "Mujeres de ojos grandes" (págs. 186, 187); o en la novela Mal de amores, cuando Milagros Veytia pronuncia uno ante su sobrina Emilia Sauri, recién nacida (págs. 26, 27). Citemos, a guisa de muestrario, éste que proviene del relato "Ninguna eternidad como la mía" y que podríamos denominar el ensalmo de la silla, proferido por la protagonista frente a la silla que compra con su primer sueldo: "Yo, Isabel Arango Priede, me comprometo a vivir con intensidad y regocijo, a no dejarme vencer por los abismos del amor, ni por el miedo que de éste me caiga encima, ni por el olvido, ni siquiera por el tormento de una pasión contrariada. Me comprometo a recordar, a conocer mis yerros, a bendecir mis arrebatos, a no desdeñar nada de todo lo que me conmueva, me deslumbre, me quebrante, me alegre. Larga vida prometo, larga paciencia, historias largas. Y nada abreviaré que deba sucederme, ni la pena ni el éxtasis, para que cuando sea vieja tenga como deleite la detallada historia de mis días".

Mastretta, Ángeles. Ninguna eternidad como la mía. Alfaguara. Bogotá, 2000. Págs. 36, 37.
} 
do, no escritor (...) No sé por qué me volví escritora, pero evidentemente no fue por mi formación. A mí me hubiera encantando ser cantante. ${ }^{6}$

No es de extrañar, pues, que algunos críticos la hubiesen emprendido contra esta exitosa novela y contra una escritora cuya figura pública se empeñó desde el comienzo en alejarse de cualquier gravedad o circunspección. ${ }^{7}$ Y resulta claro que la provocación aquí va mucho más allá de la espontánea despreocupación característica de la autora; de hecho, las técnicas compositivas presentes en Arráncame la vida se destacan por su indudable disposición para atraer y salvaguardar la atención del público, al cual propone una experiencia de lectura evidentemente amigable. No obstante, quienes han catalogado esta obra como una simple novela de entretenimiento pierden de vista las otras capas interpretativas que su escritura propicia, especialmente aquellas que se encuentran cifradas tanto en su clave irónica como en sus juegos de información implicada. Recordemos la fuerte descalificación que el crítico Christopher Domínguez Michael realizó contra esta novela en su "Antología de la narrativa mexicana del siglo XX":

Es una buena novela, tersa en sus procedimientos y sencilla en sus pretensiones. Pero su increíble éxito internacional corresponde más a las nada caprichosas leyes del comercio que a su profundidad literaria (...) Los críticos que creyeron encontrar en Arráncame la vida la llamada de un nuevo realismo se equivocaron candorosamente. Se trata de un realismo rosa que no se atreve a decir su nombre, plagado de guiños convencionales y técnicas manidas. ${ }^{8}$

La propia Ángeles Mastretta se ha referido a aquel prejuicio de la crítica -que entiende el éxito comercial como un signo inequívoco de mediocridad estética - en los siguientes términos: “(...) en México todavía hay la teoría de que existe la literatura difícil y la fácil. Según

\footnotetext{
${ }^{6}$ Telchman, Ron. Óp. Cit.

${ }^{7}$ Fabienne Bradu arremetió reciamente contra la opera prima de Mastretta en los siguientes términos: "La mayor tragedia de esta novela es el lenguaje en el que está escrita (...) En cuanto al propósito de escribir una versión de la historia mexicana desde el punto de vista femenino, 'Arráncame la vida' llega desgraciadamente a confundir la historia con el rumor, como si ésta fuera para las mujeres un inmenso chisme".

Bradu, Fabienne. “¿Los nuevos realistas?”. En: Vuelta, 11, No 129. México, 1987. Pág. 160.

${ }^{8}$ Domínguez Michael, Christopher. Antología de la narrativa mexicana del siglo XX. Tomo II. Fondo de Cultura Económica. México, 1991. Págs. 498, 499.
} 
esto, yo hice literatura fácil. El hecho de que 'Arráncame la vida' sea un libro que gusta lo convierte inevitablemente en literatura fácil”. Y a continuación le comenta a Gabriella de Beer en esta misma entrevista: "Ha costado mucho trabajo que se imponga la idea de que atrás de la persona que escribió ese libro hay una escritora". ${ }^{9}$ Ahora bien, no pretendemos desconocer las estrategias que el mercado editorial despliega al momento de buscar la promoción y legitimación de un libro determinado. Un claro ejemplo de esto se encuentra documentado en el interesante estudio de Meg Brown, en el cual este académico reflexiona precisamente sobre los elementos extraliterarios que contribuyeron a la buena recepción de las novelas de Isabel Allende y Ángeles Mastretta en Alemania Occidental. ${ }^{10}$ Sin embargo, quisiéramos destacar el hecho de que, en el contexto latinoamericano, las resistencias de la crítica a los escritores del post-boom y sus obras están ligadas a una drástica transformación de paradigma representacional en la novela del continente. Dicho cambio se produjo concretamente respecto del experimentalismo formal del Boom, respecto de su aspiración a la "novela total", respecto de su inscripción en los parámetros de la "alta cultura". En otras palabras, los reparos que suelen leerse dirigidos a la obra de Mastretta los hallamos igualmente referidos a otros narradores y autoras de esta misma tendencia novelística.

\section{2. Ángeles Mastretta: Palabra de mujer}

Uno de los asuntos más imprecisos en relación con la obra de Mastretta se refiere a su postura sobre el feminismo; de hecho, en la crítica que se ha ocupado de su obra hallamos versiones encontradas. Y la verdad es que los planteamientos públicos de la propia autora contribuyen a crear dicha ambigüedad. Recordemos a manera de ejemplo aquello

\footnotetext{
${ }^{9}$ Beer, Gabriella de. "Entre la aventura y el litigio: una entrevista con Ángeles Mastretta". En: Revista Nexos, No 184. México, 1993. Pág. 36.

${ }^{10}$ Brown discurre sobre la expectativa de exotismo que despierta entre el público alemán un nombre como "Mexikanischer Tango", título con que se tradujo Arráncame la vida; o sobre la circunstancia de que dicha obra haya aparecido en editoriales prestigiosas que otrora publicaron a autores latinoamericanos de gran reconocimiento, como Cortázar, Vargas Llosa, Paz, Onetti o Fuentes.

Cfr. Brown, Meg. "The Allende/Mastretta Phenomenon in West Germany: When Opposite Cultures Attract.” En: Confluencia: Revista Hispánica de Cultura y Literatura, No 10. University for Northern Colorado. Northern Colorado, 1994.
} 
que le dijo a la escritora argentina Reina Roffé durante una entrevista fechada en 1999 y publicada en Cuadernos Hispanoamericanos: "Yo ya no quiero saber si existe una diferencia de género en lo que escribimos. He dicho muchas veces que no. De lo que se trata es de ser buen escritor o mal escritor, entrañable o no, que nos guste o disguste lo que leemos. Eso es lo que hace una diferencia en la literatura, no el género". ${ }^{11}$ Sin embargo, algunas críticas literarias han insistido en hacer una lectura de Mastretta poniendo sobre relieve su condición feminista, incluso atribuyéndole un carácter combativo cuya radicalidad no acaba de ser evidente. ${ }^{12}$ Aunque los roles de género, sin duda alguna, son muy importantes en la construcción de sus personajes, resulta mucho menos claro que esta narradora mexicana tenga como propósito de sus relatos la configuración de una mirada panfletaria contra la cultura patriarcal. No obstante, se encuentran con frecuencia afirmaciones críticas como ésta de Jean Franco:

(...) el general Andrés Ascencio, hombre muy mujeriego, se casa con Catalina, una muchacha de apenas 15 años; durante mucho tiempo Cata parece ser una esposa dócil a pesar de ser testiga (sic) de la crueldad, corrupción y falta de humanidad del general. La novela presenta la otra cara del mito del macho, pues la personalidad autoritaria del general genera un resentimiento oculto y el deseo de venganza que sólo puede satisfacerse cuando ha muerto y está enterrado. En ese momento, Catalina vislumbra el futuro, "casi feliz". En la alegoría antinacional, la mujer se libera cuando muere el macho. ${ }^{13}$

\footnotetext{
${ }^{11}$ Roffé, Reina. "Entrevista con Ángeles Mastretta". En: Cuadernos hispanoamericanos, N ${ }^{\circ}$ 593. Madrid, noviembre de 1999. Pág. 79.

${ }^{12}$ Pese a ello, resulta importante advertir que - en otros testimonios- Mastretta ha expresado su defensa de un punto de vista femenino en la escritura, lo cual crea la ambigüedad que estamos señalando. Al periodista Eric Nepomuceno, por ejemplo, le planteó lo siguiente: "Hay cosas que sí se escriben desde un punto de vista de mujer. Lo he empezado a creer. Es que eso viene de que cada quien escribe desde donde está (...) Pero lo que no puedes hacer es decir: No hay un punto de vista femenino. Sí hay un punto de vista, irrevocablemente. Y yo siempre decía: Bueno, los cuartos de las mujeres en las novelas de Balzac parecen descritos por una mujer. Las emociones de Madame Bovary, las de Ana Karenina. Son hombres que le dieron una prioridad grande a las mujeres. ¿Sabes qué? Ahora las he empezado a leer, y la diferencia entre las heroínas de Jane Austen y las heroínas de los hombres es que las heroínas de Jane Austen no se suicidaron".

Nepomuceno, Eric (entrevista). "Ángeles Mastretta". En: Sangue Latino. Canal Brasil, TV Cultura e Urca Filmes. Brasil, 2011.

${ }^{13}$ Franco, Jean. Las conspiradoras: la representación de la mujer en México. Fondo de Cultura Económica. México, 1994. Pág. 227.
} 
Una sinopsis de Arráncame la vida así realizada evidencia una mirada por completo tendenciosa, una mirada que no se corresponde de modo preciso con el entramado que la novela construye. Para empezar, Catalina encarna a lo largo del relato un rol de colaboración con Andrés Ascencio que resulta por completo innegable. En tal sentido, leer al personaje sólo como una víctima y no considerar su papel de aliada en muchas de las aventuras políticas, económicas y vitales de su marido equivale a incurrir en una profunda tergiversación. A propósito de los planteamientos hechos por Jean Franco, el crítico Marcelo Fuentes ha desarrollado una interesante contra-argumentación en su artículo titulado "La cantante, el gobernador, su mujer y su amante: la política del bolero". Allí leemos, entre otras, las siguientes aclaraciones:

Además de desvirtuar la relación entre Catalina y Andrés al ignorar que ella sigue amando a su esposo tras conocer sus crímenes, Franco también desfigura al general cuando señala como su mayor defecto el ser "muy mujeriego" y menciona su crueldad sin referir sus efectos: incontables homicidios, incluyendo el del amante de Catalina. Andrés no es sólo un mal marido, como sugiere la descripción de Franco, sino un criminal; del mismo modo, Catalina no es solamente su víctima, sino su cómplice: mediante el silencio que guarda frente a los delitos de Andrés, ella colabora con su propia opresión y la de otros, mientras mantiene su estatus social y su bienestar económico. ${ }^{14}$

No podría desestimarse, como algo menor, el profundo vínculo que a lo largo de la novela se establece entre Catalina y Andrés Ascencio. Tampoco podría eludirse la complejidad de esta relación, la cual incorpora en un lugar muy destacado la tremenda fuerza de su mutua atracción erótica. Y es ésta una atracción que se renueva todo el tiempo durante la historia relatada. Por otra parte, se hace necesario insistir en que no hay en la escritura ficcional de Mastretta ninguna actitud tajante que la lleve a utilizar a sus personajes como guiñoles de conceptos preconcebidos. Al contrario, el suyo es un talante de permanente indagación, de caminar a tientas tras el destino que sus personajes se van trazando. En este orden de ideas, cuando Gabriella de Beer —en la entrevista que ya hemos citado atrás- le preguntó a Ángeles Mastretta:

${ }^{14}$ Fuentes, Marcelo. "La cantante, el gobernador, su mujer y su amante: la política del bolero". En: Taller de Letras, No 35. Pontificia Universidad Católica de Chile, noviembre de 2004. Pág. 45. 
“¿Te consideras una representante de la emancipación femenina?”, ella le respondió de un modo que nos parece muy significativo:

No me gusta darme más responsabilidades de las que puedo tener. Sí creo que mis personajes son mujeres en busca de su emancipación, pero no son teóricas del feminismo. Mi intención fue valerme de la búsqueda y de la curiosidad de una mujer inconforme para contar un mundo que provocaba mi curiosidad y frente al cual no pude sino manifestarme inconforme. La conducta de mis personajes es contradictoria y no responde a ninguna voluntad teórica, sino a su propio descubrimiento de que las cosas no tenían por qué ser como eran, y de que era posible intentar vivirlas de otro modo. ${ }^{15}$

Además de esa conducta escritural ajena a todo radicalismo, Mastretta se ha expresado siempre sobre su vocación literaria en términos bastante abiertos que incluyen mucho más las dudas que las convicciones. En el bello discurso que pronunció al recibir el Premio Rómulo Gallegos de 1997 —recordemos que fue la primera mujer en obtener esta distinción-, el cual fue publicado luego en el libro misceláneo El mundo iluminado, nos dice: "Nos dedicamos a escribir un día con miedo y otro con esperanza, como quien camina con placer por el borde de un precipicio. Ayudados por la imaginación y la memoria, por nuestros deseos y nuestra urgencia de hacer creíble la quimera". Y seguidamente concluye: "No imagino un quehacer más pródigo que éste con el que di como si no me quedara otro remedio. Por eso recibo este premio más suspensa que ufana". ${ }^{16}$

Con todo, cabe preguntarse si hay otras razones que lleven a Mastretta a negar una postura feminista en sus ficciones. Y esto pese a que efectivamente todas las protagonistas de sus obras son mujeres que se esfuerzan por vivir autónoma, plenamente; $y$, de otro lado, pese al conocimiento que tiene la autora en el sentido de que una altísima parte de quienes leen sus libros y siguen con atención su obra son mujeres. Seguramente, la preocupación que está detrás de esta negativa se relaciona con los riesgos de estos rótulos que encasillan, que terminan segregando a los propios escritores, apartándolos en una especie de

\footnotetext{
${ }^{15}$ Beer, Gabriella de. Óp. cit.

${ }^{16}$ Mastretta, Ángeles. El mundo iluminado. Seix-Barral. Bogotá, 2002 (1998). Pág. 218.
} 
gueto minoritario, marginal. En otra de sus respuestas al ser interrogada sobre este asunto, Mastretta afirmó:

No, no quiero decir que no quiero escribir para las mujeres ni quiero decir que no quiero escribir como mujer. Lo que quiero decir es que quiero escribir para las mujeres pero también para los hombres, y que quiero escribir como mujer, pero también como escritor y que quiero ser tomada en cuenta como escritor y no específicamente, o solamente, como escritora. Quiero trabajar para que cuando se hable de la literatura mexicana en general yo esté en la literatura mexicana en general, y no sólo cuando hablen de la literatura mexicana femenina. Porque eso se ve como pertenecer a las ligas menores. ${ }^{17}$

Como ya hemos venido anotando, lo que sí resulta innegable es que en la obra ficcional de Mastretta las mujeres ocupan siempre un lugar preponderante, protagónico. ${ }^{18} \mathrm{Y}$ de esto se derivan las principales constantes temáticas de sus obras, los motivos que vuelven una y otra vez, que pueblan el universo narrativo de esta autora mexicana. En este orden de ideas, señalemos que su mundo por excelencia son las relaciones de pareja, vistas siempre desde una perspectiva femenina. De allí se desprenden, entonces, temas clave como la infidelidad trascendida, el deseo sexual en tanto motor de la aventura, el reencuentro con amores del pasado, el extranjero que se coliga en amores con una lugareña, la entrada en viudez como situación liberadora, los amores "golondrina" - uno de los amantes tiene vocación de nómada, así que va y viene de modo incorregible-, o la dicotomía vida pública-vida privada. Hay, sin embargo, un par de motivos que se reiteran con cierta frecuencia y que no conciernen estrictamente al universo de la pareja: el descreimiento respecto de religiones y dioses — del cual se deriva esa suerte de proselitismo ateo que profesan algunos de sus personajes, como Emilia Sauri o su tía Milagros Veytia-; y, por otra parte, el homenaje al padre — hablamos de un padre amadísimo, de algún modo

\footnotetext{
${ }^{17}$ Beer, Gabriella de. Óp. cit.

${ }^{18}$ El trabajo ficcional de Mastretta está integrado por dos novelas: Arráncame la vida (1990) y Mal de amores (1996); por dos colecciones de relatos: Mujeres de ojos grandes (1991) y Maridos (2007); y por un relato largo, tipo nouvelle: "Ninguna eternidad como la mía" (1999). Todos sus demás libros son volúmenes misceláneos, periodísticos, en los cuales se mezclan ensayos cortos con crónicas y con viñetas de carácter más o menos autobiográfico; son éstos: Puerto libre (1993), El mundo iluminado (1998), El cielo de los leones (2004) y La emoción de las cosas (2012).
} 
derrotado por circunstancias de la vida, que recibe la complicidad de una hija dispuesta siempre a reivindicar su figura.

Dado que el punto de vista que predomina en todas las narraciones de Ángeles Mastretta es femenino y que de modo invariable sus personajes principales son mujeres, quizás no forcemos demasiado esta lectura de su obra si decimos que la suya es siempre una mirada afirmativamente femenina, aunque no necesariamente feminista. Sus mujeres rigen sus vidas por un poderoso vitalismo, por una voluntad de hacerse dueñas de sus cuerpos, de sus deseos, de sus destinos. Y están tan ocupadas en ello que no tienen interés en realizar diatribas, ni en trazar descalificaciones categóricas de los hombres a quienes, por otra parte, desean y aman con intensa pasión. Dediquémonos ahora a revisar la manera en que esta escritora se acerca a otro de sus asuntos más caros: la Revolución Mexicana y sus itinerarios sociales (públicos y privados).

\section{La Revolución traicionada: poder, corrupción y vida privada}

El universo que habitan los personajes de Mastretta es México. Y, la mayoría de las veces, dicho mundo se centra en Puebla: en su geografía, en sus costumbres, en sus gentes. Hemos de señalar también que la época en la cual suelen instalarse estas vidas se corresponde o bien con los años de la Revolución Mexicana (1910 - 1924?) —especialmente la novela Mal de amores - o bien con el periodo inmediatamente contiguo, llamado también post-revolucionario. ${ }^{19}$ Bárbara Mujica nos refiere el modo en que inquirió a Mastretta sobre esta predilección histórica respecto de su trabajo ficcional:

"Creo que la Revolución Mexicana es un periodo que inició cosas, ideas", afirma Ángeles Mastretta, la exitosa autora mexicana. "Todas las revoluciones producen esto, de allí que la gente haga revoluciones: para cambiar cosas. Con frecuencia, las revoluciones producen pocos

\footnotetext{
${ }^{19}$ En este sentido, la obra de Mastretta — particularmente Mal de amores - se inscribe en la tradición de las llamadas Novelas de la Revolución Mexicana, entre las cuales se cuentan algunos textos considerados ya paradigmáticos, como Los de abajo (1915) de Mariano Azuela, El águila y la serpiente (1928) de Martín Luis de Guzmán, Cartucho: Relatos de la lucha en el Norte de México (1931) de Nellie Campobello, Memorias de un lugareño (1940) de José Rubén Romero, Los relámpagos de agosto (1964) de Jorge Ibargüengoitia, Por debajo del agua (2004) de Fernando Zamora, entre una larga serie de relatos.
} 
cambios; pero, durante un periodo revolucionario, la gente se atreve a hacer cosas increíbles. Goza de una enorme libertad. Te puedo decir que durante los 40 y 50, las mujeres mexicanas no hubieran tenido tanta libertad como en los años 20. Porque cuando una guerra está en marcha, a la gente no le importa con quién hagas el amor, si te casas o si no, si vives con alguien con o sin papeles. Esas cosas se vuelven absolutamente secundarias. Lo más importante es la vida" ${ }^{20}$

Aquí encontramos cifrado uno de los rasgos más personales en la novelística de Mastretta. Y este tiene que ver, precisamente, con la reivindicación de la vida privada. Dicho de otro modo, esta narradora mexicana, a través de su obra, señala la preeminencia de lo íntimo sobre lo público. En este sentido resulta muy significativa la manera en que se abre la narración de la novela Arráncame la vida; recordemos las palabras de Catalina: "Ese año pasaron muchas cosas en este país. Entre otras, Andrés y yo nos casamos". ${ }^{21}$ Este enfoque sobre lo personal es una toma de partido en el sentido de señalar que la existencia en general, incluida la de los grandes protagonistas de la vida política y social, discurre de modo esencial en estancias domésticas. A la grandilocuencia de los discursos públicos, a la prepotencia de la esfera política, Mastretta opone la trivialidad de lo cotidiano, la esencialidad de la vida familiar. En su breve ensayo titulado "Barcos a la deriva" leemos:

En el mundo que ahora vivo mi familia de entonces [la de su infancia] hubiera sido calificada de banal. Lo que yo creo es que sus intereses estaban puestos en los disturbios y aromas de la vida privada. El mundo de la política era tan inaccesible y desquiciado, tan caprichoso e intocable, tan temido, que la gente se limitaba a ignorarlo.

Vivíamos regidos por ensueños que volvían importantes las cosas

20 "'I Think that the Mexican Revolution is a period that initiated things, ideas', says Mexico's bestselling author Angeles Mastretta. 'All revolutions do that. That's why people make revolutions, to change things. Lots of times revolutions change very little. But during a revolutionary period, people dare incredible things. They enjoy an enormous amount of freedom. I can tell you that there's no way that during the forties and fifties Mexican women had as much freedom as during the twenties. Because when a war is going on, people don't care who you make love with, if you get married or you don't, if you're living with someone with or without papers. Those things become absolutely secondary. The most important thing is life",.

Mujica, Bárbara. “Ángeles Mastretta: Women of Will in Love and War”. En: Revista Américas (OEA), Volumen 49, № 4. Washington, julio-agosto de 1997. Pág. 37. (La traducción es nuestra.)

${ }^{21}$ Mastretta, Ángeles. Arráncame la vida. Seix-Barral. Barcelona, 2009 [1985]. Pág. 7. 
más triviales. Del mismo modo en que otros convierten en ensueños los resultados de unas elecciones, las cifras de los censos, las ocho columnas de los periódicos. ${ }^{22}$

Esto no significa, sin embargo, que esta escritora se ponga de espaldas a la realidad histórica. De hecho, la base de sus relatos se encuentra fuertemente entroncada con algunos de los momentos y personajes más importantes de la historia mexicana. Lo que sucede es que en su manera de abordarlos, de acometer la narración, decide poner la lupa sobre sus vidas privadas. Al comentar el modo en que Mastretta construye los relatos que conforman su libro Mujeres de ojos grandes, Ana Figueroa afirma justamente: "Otra forma de mostrar la historia de Puebla y de sus habitantes es a través de las acciones que, para los personajes, constituyen su cotidianidad"; de manera que entonces, nos dice, "los hechos que ocurren en la cocina, en el mercado, en la iglesia, son parte importante de la narración que va conformando la ciudad y el modo de ser de su gente". Y concluye: "En su descripción, la narradora va más allá del mero acontecer de los 'grande hechos': lo que se cuenta es la ciudad por dentro". ${ }^{23}$ Estas mismas aseveraciones podrían hacerse sobre los relatos de Maridos — los cuales han sido considerados por la propia Mastretta como una continuación de Mujeres de ojos grandes y sobre la nouvelle Ninguna eternidad como la mía.

En el caso de la novela Mal de amores, lo que tenemos es un amplio recorrido por los grandes acontecimientos de la Revolución Mexicana. Gracias a la vocación revolucionaria de Daniel Cuenca, el lector tiene acceso a los sucesos más importantes de este periodo histórico en el país azteca, desde sus inicios con el descontento creciente que produjo la dilatada dictadura de Porfirio Díaz (1876-1910), pasando por el periodo gobernado por Francisco Madero y por los enfrentamientos entre líderes revolucionarios - que dieron lugar a gobiernos interinos y a dictaduras intermedias como la de Victoriano Huerta-, hasta el asesinato de líderes destacadísimos como Emiliano Zapata, Venustiano Carranza y Pancho Villa. Todo esto hasta llegar a la campaña de Álvaro

\footnotetext{
${ }^{22}$ Mastretta, Ángeles Barcos a la deriva En: Puerto libre. Óp. cit. Pág. 13, 14.

${ }^{23}$ Figueroa, Ana. Escritoras hispanoamericanas: Alba Lucía Ángel, Rosario Ferré, Ángeles Mastretta, Gabriela Mistral, Sylvia Molloy, Alejandra Pizarnik: espejos-desplazamientos-fisurasdobles discursos. Ediciones Cuarto Propio. Santiago de Chile, 2001. Pág. 57.
} 
Obregón contra Pancho Villa y la final Constitución de Plutarco Elías Calles, en $1924 .{ }^{24}$ Ahora bien, todo este entramado funciona como telón de fondo; sin embargo, la historia principal de la novela está referida a la vida de Emilia Sauri y sus dramas amorosos con Daniel Cuenca y con el doctor Antonio Zavalza. Y en lo que respecta a los capítulos iniciales de la novela, éstos cuentan los amoríos de los padres de Emilia -Diego Sauri y Josefa Veytia - hasta el nacimiento de su hija. Como puede verse, aquí hallamos esa característica composicional que consiste en poner la "Gran Historia" junto a la historia privada, rasgo bastante frecuente en la novelística del post-boom. En el entramado de este texto en particular, esto puede corroborarse en muchísimos momentos, incluso en la propia estructura novelística de la obra. Ilustrémoslo refiriendo una de las tantas ocasiones en que Daniel Cuenca se ausenta de la vida de Emilia Sauri y, además, la deja sin noticias suyas durante un largo periodo: Madero había roto el arraigo a que estaba condenado en San Luis Potosí y había llegado a Texas. Desde ahí, él y quienes estaban contra la reelección de Díaz habían lanzado un documento que declaraba nulas las elecciones y convocaba a la insurrección para el veinte de noviembre a las seis de la tarde. Daniel iba a cruzar la frontera para unirse en Chihuahua a un grupo de arrieros y gente de las minas que formarían parte del levantamiento destinado a despertar al país de su letargo. ${ }^{25}$

El suceso que se narra aquí acontece el 20 de noviembre de 1910. Y se está hablando nada menos ni nada más que de los hechos que dieron inicio a la Revolución Mexicana. El punto de vista desde el cual se cuenta es el de Emilia, quien se entera de tales situaciones a través de una carta personal que su amado Daniel Cuenca le ha hecho llegar; es decir, estamos de nuevo ante la amalgama entre la vida privada y la vida nacional.

Otro tanto ocurre con Arráncame la vida. La historia de la novela empieza en 1930, el año en que una Catalina Guzmán de quince años se casa con Andrés Ascencio, de treinta y cuatro. La narración es realizada

\footnotetext{
${ }^{24}$ Resulta importante destacar que no hay consenso entre los historiadores sobre cuándo fechar el fin de la llamada Revolución Mexicana. Algunos indican la fecha de 1924, otros la de 1917, y hay quienes extienden dicho periodo hasta los años 40.

${ }^{25}$ Mastretta, Ángeles. Mal de amores. Punto de Lectura. Madrid, 2002 [1996]. Pág. 209.
} 
por la protagonista y, como bien lo anota Ramona Lagos, se trata de "un texto confesional y autobiográfico recordado desde la madurez por la propia Catalina". ${ }^{26}$ Este relato se centra en el periodo postrevolucionario y nos muestra el modo en que una burguesía emergente - cuyos miembros provienen de diferentes bandos revolucionariosse va apropiando del Estado para hacer de éste su negocio personal e imponer la defensa de sus intereses a sangre y fuego. Dicho trasfondo histórico de la relación entre Catalina y Andrés "Ascencio" podría denominarse la revolución traicionada. En tal sentido, la propia Lagos comenta el modo en que también se ha ido configurando en México una serie novelística que se ocupa del enorme desencanto social dejado por el periodo post-revolucionario y que, al mismo tiempo, desenmascara a aquellos próceres con pies de barro cuyo accionar no fue precisamente heroico. Nos dice Lagos:

Con Rulfo, Carlos Fuentes, se acentúa el examen literario del cacique y se conforman los grandes mitos del héroe o líder violento y torturado por la división entre su poder político y su fracaso personal. Pedro Páramo, Artemio Cruz, Epifanio Trujillo, son algunas de las grandes figuras trágicas más conocidas que incorpora la narrativa mexicana a la literatura post-revolucionaria para ilustrar la violencia de los cambios y la falta de un sentido de dirección claro posterior a la lucha armada. ${ }^{27}$

No olvidemos que también en Arráncame la vida hay un fuerte componente histórico ensamblado al registro ficcional. De hecho, la figura de Andrés Ascencio tiene un modelo claramente identificable en la historia real de Puebla. Nos recuerda Monique Lemaître: "En cuanto al personaje de Andrés Ascencio, su parecido con Maximino Ávila Camacho, quien como Andrés, luchó contra los cristeros y llegó a ser gobernador de Puebla, parece evidente. Los generales federales que pelearon en esa contienda eran tristemente célebres por su crueldad". ${ }^{28}$ Y quisiéramos destacar también, entre los muchos otros personajes y acontecimientos que aparecen en esta obra de Mastretta y que tienen

${ }^{26}$ Lagos, Ramona. "Metáforas de lo indecible: Gioconda Belli, Lucía Guerra y Ángeles Mastretta. Ediciones Cuarto Propio. Santiago de Chile, 2003. Pág. 220.

${ }^{27}$ Ídem. Pág. 239.

${ }^{28}$ Lemaître, Monique. "La historia oficial frente al discurso de la 'ficción' femenina en Arráncame la vida de Ángeles Mastretta". En: Revista Iberoamericana, Volumen LXII, No 174. University of Pittsburg, enero-marzo de 1996. Pág. 188. 
un correlato real-histórico, la infausta figura del Gringo Heiss, amigo y socio - en la novela- de Andrés Ascencio:

El personaje de Heiss está probablemente inspirado en el del millonario norteamericano-poblano William Oscar Jenkins Biddle, nacido en 1878 en Shelbyville, Tennessee, y muerto en Puebla en 1963. El 19 de octubre de 1919, y siendo Jenkins cónsul norteamericano en Puebla, fue secuestrado. El gobierno de Carranza lo vio como un autosecuestro inventado en Washington para justificar mayores presiones sobre Carranza mientras que los Estados Unidos lo utilizaron como ejemplo del clima de inseguridad en México bajo en gobierno del mismo Carranza, clima poco propicio para las inversiones de capitales estadounidenses. En la historia real, William Jenkins estuvo afiliado a los Ávila Camacho, especialmente a Maximino, y se dedicó a fabricar alcohol ilegalmente en los años veinte en su ingenio de Atencingo. ${ }^{29}$

Todo éste es el contexto histórico convulso y corrupto del México en que habitan Catalina y su esposo, el General Andrés Ascencio. ${ }^{30}$ Pero detengámonos ahora en los intríngulis de esta historia amorosa. Y hagámoslo poniendo de relieve la particular manera en que Mastretta apela, para contarla, al género del melodrama.

\section{El melodrama parodiado (amantes y boleros, despecho y carcajada)}

Los detractores de Mastretta — quienes la acusan de incurrir en "fórmulas manidas" - parecen perder de vista que existe una gran diferencia entre el expediente de acudir a un molde para usarlo

${ }^{29}$ Ídem.

${ }^{30}$ Nos gustaría recordar — respecto de esta idea de la revolución traicionada y carcomida por cuenta de la corrupción institucional- lo dicho por el actor Daniel Giménez Cacho cuando se estrenó la versión fílmica de Arráncame la vida. Este actor realizó allí una memorable caracterización del general Andrés Ascencio. Sus palabras son representativas del enorme descontento popular que llevó al PRI a perder en 1989 aquella hegemonía política de seis décadas en el país azteca. Dijo Giménez Cacho: "La atrocidad la vivimos a diario en el país; en la cinta lo que prima es el espíritu y visión que le imprimió la escritora: existe todo ese drama, la realidad política, al igual que las pequeñas cosas de la gente; pero el telón de fondo, el verdadero conflicto histórico, además de mostrar la liberación de una mujer, es dar a conocer cómo los mexicanos nos convertimos en los hijos del fraude, de la simulación, de la impunidad, aunque también hay seres humanos que disfrutan su vida, que tienen sus logros".

Caballero, Jorge (entrevista). “'Arráncame la vida’ muestra cómo nos volvimos hijos del fraude”. En: La Jornada. México, septiembre 2 de 2008. (El subrayado es nuestro.) 
siguiendo el recetario y, de otro lado, el recurso de apelar a dicho molde para realizar con éste operaciones paródicas. La divergencia entre estas dos opciones resulta diametral. En el primer caso estamos ante un ejercicio que evita los riesgos propios del trabajo creativo y prefiere la seguridad que ofrecen los catálogos comerciales del consumo cultural; en el segundo se invoca la complicidad de los lectores para desplegar creativamente rutas de desvío, para construir estrategias de signo irónico que puedan ser leídas entre líneas y, de este modo, renovar incluso los géneros escriturales más conservadores y esquemáticos. En su diálogo con Ana Solanes, Mastretta deja entrever su vocación de juego al trasegar las rutas del melodrama. Y lo hace a propósito de un famoso bolero de María Grever. Nos dice: "Hay una canción, que cantaba con gran cursilería Libertad Lamarque, que decía: si yo encontrara un alma, como la mía, cuántas cosas bonitas, le contaría. Yo la parodio cantando: si yo encontrara un alma como la mía, con toda certidumbre me aburriría". 31

En la entrevista que Ángeles Mastretta le concedió a Jorge Halperin —publicada en el diario "Clarín" de Buenos Aires- puede leerse de un modo todavía más explícito esta disposición paródica de la autora en relación con los géneros populares. Y no dudamos en señalar dicha proclividad como un elemento constitutivo, nuclear, de su poética narrativa. Mastretta afirmaba en aquella ocasión: "Yo no creo que debamos despreciar el melodrama (...) pero sí mejorarlo (...) el gran chiste de hacer literatura con el melodrama es ponerle adentro ironía, sentido del humor y malicia". ${ }^{32}$ Detengámonos un poco más en dos elementos centrales que, siendo inherentes a este género desde sus orígenes, resultan transgredidos o parodiados en el trabajo narrativo de nuestra novelista mexicana. Nos estamos refiriendo, de modo puntual, al intrínseco moralismo típico del melodrama y, por otra parte, a la construcción recurrentemente esquemática de sus personajes. Partamos del hecho, constatable históricamente, de que el término melodrama designa un tipo particular de representación escénica y novelística cuyas características están ligadas tanto a los gustos como a las axiologías

\footnotetext{
${ }^{31}$ Solanes, Ana. Óp. cit. Pág. 130.

${ }^{32}$ Halperin, Jorge. "Ángeles Mastretta. Morirse de la risa con el melodrama". En: Cultura y Nación, diario Clarín. Buenos Aires, agosto 12 de1992. Pág. 5.
} 
populares; asimismo — de forma muy evidente—, al afán moralizador de sus autores y de su público. ${ }^{33}$

No deja de resultar llamativo el hecho de que este rasgo sea el mayor causante de las valoraciones contrapuestas que siempre se han cernido sobre éste. El público masivo se complace en un tipo de relato que abraza los valores aceptados socialmente, en los cuales el bueno siempre se premia y el malo recibe - invariablemente - un castigo proporcional a su fiereza. La crítica académica suele mostrarse mucho más ecléctica $\mathrm{y}$, por tal razón, considera que un género tan maniqueo tergiversa por ello mismo la profunda complejidad de la condición humana. Ahora bien, esta disposición moralizadora está relacionada, desde sus inicios, con la difícil legitimación cultural del melodrama como género representacional. Recordemos lo planteado a este respecto por Thomasseau:

Los creadores trataron en primer lugar de dotar al género recién creado de un estatuto literario y teatral reconocido. Este deseo no debe separarse de la idea de una misión educadora que se le atribuyó al género: al contrario, va unido a ella. Pixérécourt [Nancy, Francia,1773-1844] confesaba con toda lucidez que él escribía para gentes "que no sabían leer". Para este público nuevo, inculto en su gran mayoría, al que se le deseaba inculcar principios de sana moral y de buena política, había que elaborar una estética que fuera estricta y prestigiosa a la vez. Para lograrlo, los melodramaturgos atenuaron los extremismos revolucionarios, implantaron sus códigos en nombre de la verosimilitud y la decencia, aspirando en una primera época a vincular el espíritu del melodrama con el prestigio de la tragedia. ${ }^{34}$

\footnotetext{
${ }^{33}$ En su interesante estudio sobre este género, Jean-Marie Thomasseau rastrea, entre otras cosas, la historia del vocablo: "La palabra melodrama, entonces, se convirtió insensiblemente en un término cómodo, que servía para definir obras que escapaban a los criterios clásicos y que utilizaban la música como apoyo de sus efectos dramáticos. Desde 1790, el término se utilizó corrientemente por los cronistas teatrales y los autores, que introdujeron en sus obras monólogos líricos acompañados de música (...) En 1795, la palabra adopta una nueva significación: pasa a designar un nuevo género muy apreciado en esta época: la pantomima muda o dialogada, y el drama de gran acción (...) En un comienzo, y salvo para los críticos clásicos, el término no tenía un sentido despectivo. En 1835, fue adoptado oficialmente por la Academia, en el momento en que caía en desuso".

Thomasseau, Jean-Marie. El melodrama. Fondo de Cultura Económica. México, 1989. Pág. 16.

${ }^{34}$ Ídem. Pág. 28.
} 
La impronta de proclamar la "sana moral", de favorecer la "decencia", ha seguido acompañando la representación melodramática en los siglos posteriores y hasta nuestros días. $\mathrm{Y}$ se ha mantenido vigente al colonizar aquellos medios expresivos en que el arte de la ficción llegó a proyectarse en tiempos más recientes —nos referimos a los soportes radiofónicos, cinematográficos, televisivos, etc.- - Así, su espectro de influencia hacia los públicos masivos no ha hecho más que ensancharse con los diferentes desarrollos tecnológicos y culturales. Pero hemos de encaminarnos ahora a analizar lo sucedido con la narrativa de Ángeles Mastretta y su específica manera de acometer el melodrama en la escritura de sus obras. Digámoslo desde un principio: el perfil de las heroínas que protagonizan sus textos está lejos de aquella "inocencia perseguida" tan característica del género. No estamos ante ese tipo de mujer empecinada en personificar la probidad más cara a la cultura patriarcal - que pasa por valores incuestionables como la fidelidad y la maternidad-; en otras palabras, las mujeres de Mastretta no están interesadas en representar la "virtud", ni mucho menos en ser veneradas y posteriormente glorificadas en los altares del hogar. Muy por el contrario, el principal horizonte de sus vidas se refiere a la reivindicación de su cuerpo y a la afirmación de su propio deseo.

Una y otra vez estas mujeres operan transgresivamente en relación con los paradigmas morales más conservadores. Las protagonistas de sus dos novelas - Catalina Ascencio en Arráncame la vida y Emilia Sauri en Mal de amores- viven sus cuerpos con total liberalidad. Más aún: podemos afirmar que la gran potencia de estos personajes viene dada precisamente por su capacidad de entregarse a los avatares del deseo. Éste es el principal motor que las conduce siempre a la aventura, que las lleva incluso a asumir la infidelidad como una experiencia perfectamente natural. En el caso de Catalina, a lo largo de la novela vemos cómo diversos amantes se suceden unos a otros sin que tal circunstancia en sí misma le genere culpas o autocrítica alguna - esto sobre la base de recordar que su propio marido, Andrés Ascencio, ha propiciado dicha conducta a partir de su promiscuidad y su desfachatez-. Pero quizás la contravención más significativa en este sentido, referida al arquetipo tradicional del melodrama, la constituye lo sucedido a Emilia Sauri. 
Recordemos que una de las estrategias distintivas del melodrama consiste en privilegiar a lo largo del entramado las historias amorosas y en utilizar, como recurso dramático, el conflicto del triángulo pasional.

Ahora bien, en el melodrama clásico dicho triángulo se resuelve siempre a favor del romance entre la heroína y el héroe; de hecho, la consolidación de este amor y el castigo del villano son, invariablemente, los elementos nucleares del desenlace de la trama. En efecto, Mal de amores nos cuenta el conflicto que vive Emilia Sauri en su relación amorosa con el pasional y revolucionario Daniel Cuenca, siempre inmerso en gestas incompatibles con la vida marital. Sin embargo, lo que incrementa la situación dramática de la protagonista es la aparición del médico Antonio Zavalza — hombre de vida tranquila y vocación hogareña-, quien se propone cortejar a Emilia. Quizás uno de los mejores momentos narrativos de esta novela se realiza en el encuentro amoroso de la protagonista y el médico, contado en el capítulo XXVI. Tras esta concreción amatoria, que en ningún momento implica una renuncia al intempestivo e intermitente amor de Daniel, Emilia se confiesa con su familia. Nos dice el narrador:

Habían desayunado juntos para asegurarse de que estaban de acuerdo, y no debían preocuparse por Emilia que de seguro dormía por fin entre los brazos de Zavalza. Cuando la oyeron entrar, se miraron en silencio y siguieron bebiendo su café. Emilia irrumpió en ese silencio con el gesto de un pájaro y los besó a uno por uno. Fue a sentarse junto a su padre, se sirvió café, tomó aire y les dijo con una sonrisa:

- Soy bígama.

—El cariño no se gasta — le contestó Milagros Veytia.

- Ya iré viendo - dijo Emilia sin quitar de su boca la sonrisa de bienestar que le tenía tomado el cuerpo. ${ }^{35}$

Pero es seguramente el desenlace de la novela lo más elocuente en este sentido. Antes que realizar una opción definitiva por alguno de los amores que atraviesan su vida, Emilia Sauri continúa hasta el final de sus días aquella alternancia entre dos hombres. No hay resolución del triángulo amoroso. No hay reproches ni hay castigos morales o sociales para esta mujer que desafía así al establecimiento patriarcal. He aquí un

${ }^{35}$ Mastretta, Ángeles. Mal de amores. Punto de Lectura. Madrid, 2002. Pág. 370. 
elemento esencial del melodrama que resulta abiertamente transgredido por la escritura de Mastretta. En el análisis que hace sobre este género representacional en la novela Arráncame la vida, Aída Apter-Cragnolino advertía:

La novela rosa no transgrede, sin embargo, el orden y la moral social ya que si el amor redime cuando es socialmente legítimo, puede perder irremediablemente (principalmente a la mujer) si es ilegítimo. La novela sentimental no invierte tampoco, a pesar del ethos del amor-pasión que la consume, los estereotipos sexuales tradicionales. El dominio masculino nunca de desafía realmente. ${ }^{36}$

Resulta evidente, a esta parte, que dicha preceptiva no rige en modo alguno la escritura ficcional de nuestra novelista mexicana. Vale la pena señalar con insistencia este núcleo temático en la cosmovisión de Ángeles Mastretta, pues la infidelidad es sin duda uno de los elementos más recurrentes en toda su obra narrativa. No olvidemos que en sus dos libros de cuentos, Mujeres de ojos grandes (1991) y Maridos (2007), buena parte de los relatos cuentan precisamente historias de amantes clandestinas. ${ }^{37}$ Dejemos, sin embargo, otra constancia de ello recordando las palabras que nos dice el narrador hacia el capítulo final en Mal de amores:

Antonio Zavalza lo supo siempre. Con ese conocimiento estuvo hilado desde el principio el fino enlace de su complicidad con Emilia Sauri. Era un hombre extraño entre los hombres, querible como ningún otro, porque como ningún otro fue capaz de comprender la riqueza de alguien que sin remedio y sin pausa tiene fuerzas para dos amores al mismo tiempo. ${ }^{38}$

La segunda gran transgresión que efectúa la narrativa de Mastretta frente a la axiología conservadora del melodrama tiene como blanco un

\footnotetext{
${ }^{36}$ Apter-Cragnolino, Aída. "Jugando con el melodrama: género literario y mirada femenina en 'Arráncame la vida' de Ángeles Mastretta". En: Revista Confluencias, Volumen 11, No 1. University for Northen Colorado, 1995. Pág. 127.

${ }^{37}$ De los 37 cuentos que componen el volumen titulado "Mujeres de ojos grandes", 13 desarrollan específicamente el tema de la infidelidad. En el libro "Maridos", de los 49 cuentos que allí se recogen, 15 se ocupan de este mismo asunto.

${ }^{38}$ Mastretta, Ángeles. Mal de amores. Óp. cit. Pág. 393.
} 
valor que en las sociedades más tradicionales se considera intocable: la maternidad. Dado que estamos ante uno de los fundamentos de la institución familiar, este principio no admite cuestionamientos en la cultura patriarcal. Una sociedad regida por este paradigma asume — sin la más mínima opción de salvedad o reparo- que la mayor realización posible de toda mujer llega cuando se convierte en madre; en consecuencia, dicha condición de madre viene a constituir la recompensa más alta que puede recibir biológica y socialmente cualquier mujer. En las acertadas páginas que Consuelo Meza Márquez le dedica a la novela Arráncame la vida - al ocuparse analíticamente de diversas escritoras mexicanas - se recalca la forma absolutamente contrapuesta como Catalina Ascencio vive la maternidad y el dramatismo que tal circunstancia le genera. Nos dice Meza Márquez: "Como madre, Catalina no asimiló el deber ser: los embarazos representaban una pesadilla, rechazaba los cambios de su cuerpo y se sentía poseída por un ser extraño y ajeno a ella". Y más adelante agrega estas consideraciones que dan cuenta de una especie de insurrección íntima llevada a cabo por Catalina: "La personaja (sic), hasta cierto punto, tiene control sobre su cuerpo. Rechaza las concepciones de la maternidad y del amor maternal como instintivos, así como la imagen de la madre sin vida propia, abnegada y sacrificada. Controla su maternidad y desafía el rígido código moral que se adscribe a la mujer". ${ }^{39}$

En diferentes momentos de esta novela encontramos la voz de Catalina lanzando cáusticas diatribas contra la condición de madre, contra lo que considera su absurda idealización, contra los cambios físicos que provoca el embarazo — los cuales, a su juicio, deforman y estropean el cuerpo femenino-, contra los "lastres y obligaciones espeluznantes de la maternidad". ${ }^{40}$ Pero quedémonos ilustrativamente con el diálogo que se lee en el capítulo X, cuando la protagonista se encuentra con su buena amiga Bibi — quien está embarazada- y le protesta porque no le habla con sinceridad sobre el envío de su primer

\footnotetext{
${ }^{39}$ Meza Márquez, Consuelo. La utopía feminista. Quehacer literario de cuatro narradoras mexicanas contemporáneas. Universidad Autónoma de Aguas Calientes / Universidad de Colima. México, 2000. Págs. 105, 107.

${ }^{40}$ Mastretta, Ángeles. Arráncame la vida. Óp. cit. Pág. 214.
} 
hijo a un internado militar y sobre su actual circunstancia. La cita inicia con el reproche que Catalina le hace:

-Quiero que no me trates como si fuera yo una pendejada. Esa historia de la felicidad de tu hijo cuéntasela a Chofi, si quieres hasta te ayudo con los detalles, pero conmigo podrías llorar, ¿o no tienes ganas?

-No, no tengo ganas. No por eso. A veces lloro, pero por la panza y el encierro.

- Son horribles las panzas, ¿no?

-Horribles. Yo no sé quién inventó que las mujeres somos felices y bellas embarazadas.

- Seguro que fueron los hombres. Ahora, hay cada mujer que hasta pone cara de satisfacción.

- ¿Qué les queda?

- Pues siquiera el enojo. Yo mis dos embarazos los pasé furiosa. Qué milagro de la vida ni qué fregada. ${ }^{41}$

Como hemos podido rastrear, Ángeles Mastretta revisita el melodrama de modo transgresor para ensanchar los rígidos moldes de su estructura y abrirlos a nuevas perspectivas tanto axiológicas como estéticas. Lo propio hace con otras formas de la cultura popular, como las supersticiones, la cocina autóctona o el bolero. Y pese a las diatribas que estos procedimientos le han acarreado —dado que algunos críticos ven en ellos una mera estratagema con fines comerciales-, lo cierto es que su narrativa no se limita a una utilización mecánica de dichos recursos. Más bien diríamos: Mastretta los incorpora orgánicamente a su mundo ficcional y los resignifica. Compartimos, en este orden de ideas, la objeción que plantea Linda Egan cuando afirma: “(...) si se estudia detenidamente cada artefacto cultural en su contexto y en función de su contribución al argumento y el desarrollo de la caracterización, es evidente que la cultura popular es, por así decirlo, otro personaje más de la novela, y que desempeña un rol activo y semántico". ${ }^{42}$ Esto es precisamente lo que sucede con el bolero en la novela Arráncame la vida, donde incluso el título de la obra proviene de una famosa canción de Agustín Lara. Anotemos además que ésta es una suerte de narración con

${ }^{41}$ Ídem. Pág. 102.

${ }^{42}$ Egan, Linda. "Tragicomedia de la transgresión en "Arráncame la vida". En: Signos Literarios, Número 3. Universidad Autónoma Metropolitana-Iztapalapa, enero-junio 2006. Pág. 90 . 
banda sonora, o una especie de novela con cancionero. A lo largo de su entramado se dejan escuchar numerosos temas musicales de la tradición popular mexicana, como "Contigo en la distancia", "Temor", "La barca de Guaymas", "Qué chula es Puebla”, "Palmeras", "Obsesión”, "La noche de anoche", "Cenizas", "Contigo en la distancia", Arráncame la vida, "El jinete", "Farolito", "Sobre las olas", entre otras referencias musicales distintas que incluyen fragmentos de Mahler y el Himno Nacional Mexicano. ${ }^{43}$

El crítico Álvaro Salvador realizó un análisis de Arráncame la vida en el cual revisa, justamente, el trasfondo simbólico que juega el homónimo bolero de Agustín Lara en la obra de Mastretta. En dicho estudio afirma: "La novela se estructura a partir de un núcleo marginal, el modelo que le ofrece un producto típico de la industria cultural contemporánea: el bolero". Resulta interesante este estudio, pues nos permite asomarnos de nuevo - como hemos venido planteando- a la complejidad semántica que se esconde tras la aparente sencillez que caracteriza la escritura de la autora. Dicho bolero, que se referencia in extenso en el capítulo al cual aludíamos previamente, abre una profusión de significados que contribuye a densificar el trabajo ficcional de Mastretta. Nos dice Álvaro Salvador:

(...) el bolero en nuestro caso no se limita a ser una simple ilustración de la peripecia amorosa a que aludimos, ni el título de la novela es un capricho casual o arbitrario. En realidad, este bolero, Arráncame la vida, actúa como andamiaje fundamental del relato y se dirige a un segundo destinatario estableciendo la trama simbólica de la relación amorosa verdaderamente pertinente en el texto, la que une a la protagonista narradora con su marido el general Andrés Ascencio. ${ }^{44}$

Quisiéramos describir, en esta revisión del modo paródico en que Mastretta apela a los géneros populares, un ingenioso procedimiento

\footnotetext{
${ }^{43}$ Recordemos que el capítulo XVI de esta novela contiene además un duelo de boleros en el que participa la famosa cantante Toña La Negra y los protagonistas del relato: Andrés, Catalina y Carlos Vives (el amante de ésta).

Cfr. Mastretta, Ángeles. Arráncame la vida. Óp. cit. Págs. 147-150.

${ }^{44}$ Salvador, Álvaro. "Novelas como boleros, boleros como novelas: Una lectura de "Arráncame la vida"”. En: Anales de Literatura Hispanoamericana, № 28. Universidad Complutense de Madrid, 1999. Págs. 1176, 1183.
} 
realizado por la autora. Éste se refiere a la construcción de sus personajes. Bien conocido es el maniqueísmo característico de los tipos con los cuales funciona el melodrama. Thomasseau lo refiere en los siguientes términos: "La división de la humanidad, según el melodrama clásico, es simple e intangible: los buenos de un lado, los malos del otro. Y entre ellos no hay compromiso posible. Estos personajes, construidos de una sola pieza, representan valores morales particulares". Posteriormente agrega: "Los personajes del melodrama son 'personae', máscaras en su comportamiento y lenguaje, fuertemente codificadas e identificables de inmediato. Esta tipología, que se caracteriza por la fijeza de los tipos, se reduce a algunas entidades principales". ${ }^{45}$ Dicha circunstancia hace que no sólo sean esquemáticos los entramados del melodrama, sino que las reacciones de sus personajes ante circunstancias conflictivas resulten bastante previsibles a lo largo de la narración. Estas historias destacan siempre el drama de carácter amoroso; asimismo, en la gramática esencial del relato, sus personajes se centran en cuatro figuras principales: el villano, la heroína, el héroe y el cómico. Veamos a continuación algunos comentarios simbólicos y estructurales que sobre cada uno de ellos nos aporta Thomasseau.

Sobre el villano afirma: "Hábil para deslizarse en la noche envuelto en un manto oscuro, para saberlo y vigilarlo todo, parece movido sólo por la ambición o la venganza (...) El malvado, merced a la persecución a que somete a su víctima, es el motor del melodrama. Sin sus maquinaciones, la anécdota perdería lo fundamental de su naturaleza". En relación con la heroína, comenta: "Las heroínas del melodrama suelen ser una esposa ejemplar, pero más que nada una madre, a quien se separa de sus hijos. Buenas, bellas, sensibles, con una inagotable capacidad de sufrir y llorar, padecen una doble sumisión, filial y marital, así como las consecuencias de actos irreparables". Respecto del héroe, leemos: "La característica fundamental de todos los héroes de melodrama es ser puros y sin mácula, y oponer a la negrura de los designios del malo una virtud sin claudicaciones". Finalmente, sobre el cómico nos dice: se le adjudica "al personaje cómico la función de intervenir inmediatamente después, o algunos instantes antes, de las escenas más patéticas. La dificultad para el dramaturgo consistía en reducir la artificiosidad de

${ }^{45}$ Thomasseau, Jean-Marie. Óp. cit. Págs. 41, 42. 
esta inclusión cómica" ${ }^{46}$ Pero, ¿cómo desarrollar personajes complejos dentro de un paradigma de caracterización tan específico y cerrado? Si revisamos detenidamente las funciones que cumplen a lo largo del relato los protagonistas de Mastretta, nos llevaremos una sorpresa.

Lo primero que haremos será señalar que, en el caso de Arráncame la vida, hay una fuerte condensación de las funciones narrativas esenciales; es decir, los personajes fundamentales son sólo dos: Catalina y Andrés Ascencio - recordemos que las figuras a partir de las cuales se construyen los triángulos amorosos son absolutamente episódicas, incluida la de Carlos Vives- Esto nos lleva a percibir que a lo largo de la historia se presenta un fenómeno que podríamos denominar acumulación de roles. No olvidemos, por otra parte, que Mastretta no aplica en sus ficciones el maniqueísmo propio del melodrama, lo cual le permite contravenir la alineación irreconciliable entre buenos y malos. Y es precisamente por esta ruta creativa como arriba la autora a la construcción de sus personajes mixturados. Tal es el caso de Andrés Ascencio, quien lleva a cabo simultáneamente los papeles del héroe y del villano. Recordemos que desde la primera página de la novela — cuando la narradora conoce a Andrés- la descripción inicial que hace de él nos da la clave de este doble rol, de esta anómala oscilación entre el bien y el mal. Nos dice Catalina: "Dijo su nombre y se sentó a conversar entre nosotros. Me gustó. Tenía las manos grandes y unos labios que apretados daban miedo y, riéndose, confianza. Como si tuviera dos bocas". ${ }^{47}$ Catalina, a su vez, encarna a la heroína y, en reiterados momentos, al cómico; dicho de otro modo, ella es quien sufre y goza, quien vive y satiriza. Esta extraña caracterización dota a lo personajes, sin embargo, de una gran potencia dramática y los aleja de cualquier estereotipo. Los réditos narrativos de un proceder tan heterodoxo saltan a la vista: ni Catalina ni Andrés dejan de sorprendernos con su accionar a todo lo largo de la trama; y, cuando se entrecruzan en sus duelos verbales, aquellos contrastados diálogos se revelan de modo tan poderoso como chispeante.

Si tuviésemos que ejemplificar los momentos de la novela en los cuales se percibe con mayor nitidez el rol de héroe llevado a cabo por Andrés, indicaríamos la primera etapa de su conquista amorosa

${ }^{46}$ Ídem. Págs. 44-45, 46, 47, 48.

${ }^{47}$ Mastretta, Ángeles. Arráncame la vida. Óp. cit. Pág. 7. 
de Catalina, cuando se propone deslumbrar - y lo consigue- a la muchacha y a su familia (capítulo I). La segunda ocasión se la concede el eficaz artificio de construir a Eulalia, su primera esposa revolucionaria y mártir, valiente e idealizada, cuya imagen sirve de modelo a la joven Catalina y opera sobre ella un verdadero deslumbramiento (capítulo IV). No obstante, luego de estas circunstancias viene lo que llamaríamos la deflación de este héroe ilusorio, cuando Catalina descubre que toda aquella historia de Eulalia es una farsa. Andrés la confronta con su habitual cinismo: “¿Entonces qué? ¿No quieres ser gobernadora?”. Y la narradora nos dice: "Lo miré, nos reímos, dije que sí y olvidé el intento de crearle un pasado honroso". ${ }^{48}$ En lo que toca a su rol de villano, los ejemplos abundan a lo largo de la novela. Sin embargo, hay dos particularmente representativos por su grado de crueldad: el crimen de Atencingo, en el cual más de cincuenta campesinos — niños incluidosson asesinados por el ejército a órdenes de Andrés (capítulo VII). Y está también, desde luego, el asesinato de Carlos Vives (capítulo XIX), que corresponde al episodio más doloroso en la vida de Catalina, quien narra así el encuentro del cadáver: “Abrí la puerta, me encontré con su cabeza. Le acaricié el pelo, tenía sangre. Le cerré los ojos, tenía sangre en el cuello y la chamarra. Un agujero en la nuca". ${ }^{49}$

Respecto a los roles que desempeña Catalina a lo largo del relato, el más notorio es el de heroína; de hecho, su protagonismo en la novela resulta doble: como personaje y como narradora. Tengamos en cuenta, además, que esta novela nos cuenta el amplio proceso de aprendizaje llevado a cabo por ella —el descubrimiento de su sexualidad, su formación como mujer, el despertar de su consciencia, la conquista siempre relativa de su autonomía-; en otras palabras, recordemos que estamos ante un Bildungsroman. De los muchos momentos en que ella encarna a la heroína, destacaríamos dos, muy cruciales ambos para su consolidación como sujeto. El primero de ellos se refiere a su descubrimiento del placer, cuando —en su inquietud por aprender a "sentir"- recibe de una gitana esta instrucción:

${ }^{48}$ Ídem. Pág. 44.

${ }^{49}$ Ídem. Pág. 185. 
Aquí tenemos una cosita —-dijo metiéndose la mano entre las piernas-. Con ésa se siente. Se llama el timbre y ha de tener otros nombres. Cuando estés con alguien piensa que en ese lugar queda el centro de tu cuerpo, que de ahí vienen todas las cosas buenas, piensa que con eso piensas, oyes y miras; olvídate de que tienes cabeza y brazos, y ponte toda ahí. Vas a ver si no sientes. ${ }^{50}$

Un segundo momento clave en la difícil construcción de su autonomía se presenta cuando Catalina aprende a conducir automóvil. Esta situación — que la protagonista realiza a espaldas de Andrés- se nos cuenta en el capítulo XII de la novela. En lo que tiene que ver con su registro cómico, especifiquemos que éste se desarrolla especialmente a través de aquellos diálogos en los cuales Catalina confronta a su marido con desparpajo y, de esta manera, ridiculiza el patrón Machista que rige el mundo en que viven. La primera oportunidad para hacerlo es propiciada por la solemnidad absurda de su precoz matrimonio:

Yo no tenía firma, nunca había tenido que firmar, por eso nada más puse mi nombre con la letra de piquitos que me enseñaron las monjas: Catalina Guzmán.

—De Ascencio, póngale ahí, señora —-dijo Andrés, que leía tras mi espalda.

Después él hizo un garabato breve que con el tiempo me acostumbré a reconocer y hasta hubiera podido imitar.

— ¿Tú pusiste de Guzmán? — pregunté.

-No, m'ija, porque no es así la cosa. Yo te protejo a ti, no tú a mí. Tú pasas a ser de mi familia, pasas a ser mía — dijo.

- ¿Tuya?

A continuación, ella se percata de que Andrés no ha venido acompañado de su familia. En su lugar han venido dos amigos, uno de los cuales oficia en calidad de testigo. Catalina protesta y esto genera una situación carnavalesca. Veamos:

- Si firma Rodolfo, también que firmen mis hermanos — dije yo.

-Estás loca, si son puros escuincles.

- Pero yo quiero que firmen. Si Rodolfo firma, yo quiero que ellos firmen. Ellos son los que juegan conmigo - dije. 

Andrés.

—Que firmen, pues, Cabañas, que firmen también los niños — dijo

Nunca se me olvidarán mis hermanos pasando a firmar. Hacía tan poco que habíamos llegado de Tonanzintla que no se les quitaba lo ranchero todavía. Bárbara estaba segura de que yo había enloquecido y abría sus ojos asustados. Teresa no quiso jugar. Marcos y Daniel firmaron muy serios, con los pelos engomados por delante y despeinados por atrás. $^{51}$

No quisiéramos, al cerrar este punto, dejar la sensación de que nuestra novelista practica el melodrama tímida o tenuemente. Al contrario: la suya es una apuesta por enriquecer el género, como hemos venido planteando, lo cual la sitúa en las antípodas de cualquier negación. Hemos pues de subrayar que la filiación melodramática de Mastretta ha sido clara de forma reiterada a lo largo de su obra, como en aquella apología del sentimentalismo que está en su breve ensayo titulado Don de lágrimas. Allí leemos: "Casi cualquiera de nosotros ha tenido al menos un buen maestro del don del llanto, aunque a diario traicionemos sus enseñanzas para complacer al buen gusto y al arte de fingir fortaleza". ${ }^{2}$

A esta parte podemos afirmar que la narrativa de Ángeles Mastretta construye unas coordenadas de representación literaria cuya mirada es mucho más femenina que feminista, en el sentido de que no está antecedida de una conceptualización teórica ni regida por propósitos proselitistas. Más bien diríamos que sus ficciones están orientadas por el recorrido de unas protagonistas dispuestas a conquistar su destino, su propio cuerpo - con todo y sus itinerarios en la búsqueda del placer-. Mastretta se resiste a la victimización de sus personajes: sus mujeres no perecen en ningún "sacrificio final" — tan característico de las heroínas de la tradición literaria - sino que se afirman en su exploración vital; de allí la predilección de la autora por los finales abiertos. Y aunque en sus periplos no suelen lograr la autonomía plena, sí hay en estas mujeres una clara incorporación del goce, de la vivencia hedónica, así como una evidente conquista de su capacidad para tomar determinaciones propias. En lo que toca a la relación con sus hombres, se advierte en

${ }^{51}$ Ídem. Págs. 14, 15.

${ }^{52}$ Mastretta, Ángeles. “Don de lágrimas”. En: Puerto libre. Óp. cit. Pág. 68. 
ellas una mirada burlona, a veces compasiva y, en todos los casos, decididamente orientada por el deseo. De otra parte, nos hallamos ante una obra cuyo principal núcleo de atención está puesto en la vida privada, en la dimensión doméstica. Desde allí se indagan los recorridos vitales de sus personajes, desde esta perspectiva se miran los grandes acontecimientos de la historia mexicana del siglo XX. Hay aquí una apuesta a fondo por desacralizar tanto los mitos como los héroes del periodo revolucionario y post-revolucionario. Finalmente, en lo que se refiere a su modo de aproximarse a los registros de la cultura popular, Mastretta se reserva siempre la posibilidad de hacerlo de un modo libre, abierto; pero, fundamentalmente, renovador. Y esto lo hace procurando no afectar la fruición de sus lectores, pues, tal como se lo planteó a Bárbara Mujica, su escritura está gobernada por un fuerte propósito de agradarlos: "Lo que me gusta es escribir libros que den a la gente algo así como un boleto de avión para irse a otro mundo, algo así como la oportunidad de fantasear, de soñar, de sentir otro mundo, de sentir que ellos pertenecen a otro mundo". ${ }^{53}$

\section{Bibliografía}

Cantero Rosales, M. Á. (2004). El "Boom femenino" hispanoamericano de los años ochenta, un proyecto narrativo de "ser mujer". Granada: Universidad de Granada.

Domínguez Michael, C. (1991). Antología de la narrativa mexicana del siglo $X X$. México: Fondo de Cultura Económica.

Figueroa, A. (2001). Escritoras hispanoamericanas: Alba Lucía Ángel, Rosario Ferré, Ángeles Mastretta, Gabriela Mistral, Sylvia Molloy, Alejandra Pizarnik: espejos-desplazamientos-fisuras-dobles discursos. Santiago de Chile: Ediciones Cuarto Propio.

Franco, J. (1994). Las conspiradoras: la representación de la mujer en México. México: Fondo de Cultura Económica.

Lagos, R. (2003). Metáforas de lo indecible: Gioconda Belli, Lucía Guerra y Ángeles Mastretta. Santiago de Chile: Ediciones Cuarto Propio.

53 "What I like is to write books that give people something like an airplane ticket to another world, something like a chance to fantasize, to dream, to feel another world, to feel like they belong to another World".

Mujica, Bárbara. Óp. cit. Pág. 41. (La traducción es nuestra.) 
Lavery, J. E. (2005). Ángeles Mastretta: Textual Multiplicity. New York: Tamesis,

Woodbridge.

Mastretta, Á. (2009). Arráncame la vida. Barcelona: Seix Barral. . (2004). El cielo de los leones. Bogotá: Seix Barral. . (2002). El mundo iluminado. Bogotá: Seix Barral. . (1975). La pájara pinta. México: Poesía. . (2002). Mal de amores. Madrid: Punto de Lectura. . (2007). Maridos. Barcelona: Seix-Barral. . (2006). Mujeres de ojos grandes. Barcelona: Booket. . (2000). Ninguna eternidad como la mía. Bogotá: Alfaguara. . (2002). Puerto libre. Bogotá: Seix Barral.

Meza Márquez, C. La utopía Feminista: Quehacer Literario de Cuatro Narradoras Mexicanas Contemporáneas. México: Universidad Autónoma de Aguas Calientes / Universidad de Colima, Aguascalientes.

Thomasseau, J.-M. (1989). El melodrama. México: Fondo de Cultura Económica.

\section{Revistas y otros}

Apter-Cragnolino, A. (1985). "Jugando con el melodrama: género literario y mirada femenina en 'Arráncame la vida' de Ángeles Mastretta”, Revista Confluencias 1, volumen 11, Colorado: University for Northen Colorado, p. 127.

Beer, G. de. (1993). "Entre la aventura y el litigio: una entrevista con Ángeles Mastretta", Revista Nexos 184, México, p. 36.

Bradu, F. (1987). “¿Los nuevos realistas?”, Revista Vuelta 129, 11, México, p. 160.

Brown, M. (1994). "The Allende/Mastretta Phenomenon in West Germany: When Opposite Cultures Attract", Revista Hispánica de Cultura y Literatura 10, Northern Colorado: University for Northern Colorado.

Caballero, J. (2008). “'Arráncame la vida’ muestra cómo nos volvimos hijos del fraude", La Jornada, México.

Egan, L. (2006). "Tragicomedia de la transgresión en 'Arráncame la vida"”, Signos Literarios 3, México: Universidad Autónoma MetropolitanaIztapalapa, México, p. 90. 
Fuentes, M. (2004). "La cantante, el gobernador, su mujer y su amante: la política del bolero", Taller de Letras 35, Santiago de Chile: Pontificia Universidad Católica

de Chile, p. 45.

Halperin, J. (1992). “Ángeles Mastretta. Morirse de la risa con el melodrama”, Clarin, Buenos Aires, p. 5.

Lemaître, M. (1996). "La historia oficial frente al discurso de la 'ficción' femenina en Arráncame la vida de Ángeles Mastretta", Revista Iberoamericana 174, volumen LXII, Pittsburg: University of Pittsburg, p. 188.

Mujica, B. (1997). "Ángeles Mastretta: Women of Will in Love and War", Revisit Américas (OEA) 4, volumen 49, Washington, pp. 41-37.

Nepomuceno, E. (2011). “Ángeles Mastrettta”, Sangue Latino. Brasil: Canal Brasil, TV Cultura e Urca Filmes.

Roffé, R. (1999). "Entrevista con Ángeles Mastretta", Cuadernos Hispanoamericanos 593, Madrid, p. 79.

Salvador, Á. (1999). "Novelas como boleros, boleros como novelas: Una lectura de "Arráncame la vida", Anales de Literatura Hispanoamericana 28, Madrid: Universidad Complutense de Madrid, pp. 1176 - 1183.

Solanes, A. (2008). "La sabiduría es una forma de la inteligencia del alma", Cuadernos Hispanoamericanos 696, Madrid, pp. 127-128.

Telchman, R. (1987). "Con la precisión del arrebato", Revista Nexos 112, México. Recuperado de http://www.nexos.com.mx/?p=4748 